\title{
Implementasi penguatan pendidikan karakter religius
}

\author{
Hamidah Ulfa Fauziah, Edi Suhartono*, Petir Pudjantoro \\ Universitas Negeri Malang, Jl. Semarang No. 5 Malang, Jawa Timur, Indonesia \\ *Penulis korespondensi, Surel: edi.suhartono.fis@um.ac.id
}

Paper received: 01-04-2021; revised: 15-04-2021; accepted: 30-04-2021

\begin{abstract}
Abstrak
Artikel ini bertujuan untuk mendeskripsikan Implementasi penguatan pendidikan karakter religius. Penelitian dilakukan menggunakan pendekatan kualitatif, dengan teknik pengumpulan data observasi, wawancara, dan studi dokumen. Hasil penelitian menunjukan bahwa implementasi dilakukan melalui pembiasaan, penerapan, pembelajaran dan peraturan, serta kebijakan. Dampak yang diperoleh yaitu implikasi positif dari peserta didik, komitmen dan konsistensi dari pihak sekolah dan wali murid.
\end{abstract}

Kata kunci: implementasi; pendidikan karakter; religius; SMP Negeri 6 Malang

\section{Pendahuluan}

Indonesia merupakan negara yang menghargai nilai-nilai luhur bangsa, menjunjung tinggi nilai akhlak dan budi pekerti. Hal ini yang menjadikan Indonesia sebagai negara yang berbudaya. Penguatan pendidikan karakter bertujuan untuk membangun dan membekali semua warga negara terutama generasi muda dengan jiwa Pancasila. Pancasila sebagai dasar negara Indonesia, merupakan gambaran akhlak dan budi pekerti yang baik sesuai dengan budaya bangsa Indonesia.

Program penguatan pendidikan karakter merupakan salah satu upaya pemerintah terutamanya, Kementerian Pendidikan dan Kebudayaan dalam rangka mendorong terciptanya pengetahuan dan kesadaran warga sekolah dalam upaya meningkatkan pendidikan moral dan akhlak.

Implementasi merupakan pelaksanaan serangkaian kegiatan dalam rangka untuk memberikan dan membuat suatu kebijakan sehingga kebijakan tersebut dapat membawa hasil seperti yang diharapkan. Implementasi yang dimaksudkan oleh peneliti adalah proses penerapan nilai religius, sebagai salah satu unsur dalam pendidikan karakter peserta didik yang diterapkan di sekolah.

Implementasi menurut Nurdin (2002) merupakan suatu kegiatan yang bermuara pada aktivitas, aksi, tindakan atau adanya mekanisme suatu sistem, implementasi tidak hanya sekedar aktivitas, tapi suatu kegiatan yang terencana dan untuk mencapai tujuan kegiatan. Penguatan merupakan respon terhadap suatu perilaku yang dapat meningkatkan kemungkinan berulangnya kembali perilaku tersebut. Penguatan berpengaruh terhadap motivasi peserta didik untuk mempertahankan serta meningkatkan perilaku positif. Penguatan dapat diartikan sebagai suatu bentuk penghargaan, penghargaan ini tidak harus selalu berwujud materi, bisa juga dalam bentuk kata-kata, senyuman, anggukan, dan sentuhan. Penguatan menurut Barnawi \& Muhammad Arifin (2012), merupakan respon positif dalam pembelajaran yang diberikan guru terhadap perilaku peserta didik yang positif dengan tujuan mempertahankan dan meningkatkan perilaku tersebut. Tujuan dari penguatan dalam 
pembelajaran untuk meningkatkan motivasi serta perhatian peserta didik saat pembelajaran berlangsung serta dapat mengembangkan cara pikir peserta didik ke arah yang lebih baik.

Pendidikan adalah suatu kegiatan pembinaan sikap mental dalam upaya menuntun peserta didik sejak lahir untuk mencapai kedewasaan jasmani dan rohani, dalam interaksi alam beserta lingkungannya. Pendidikan diyakini sebagai instrumen yang paling penting dan strategis dalam mencapai tujuan individu dan sosial. Ki Hajar Dewantara mengartikan pendidikan sebagai penuntun, pembimbing, dan petunjuk arah bagi para peserta didik agar mereka dapat tumbuh menjadi dewasa sesuai dengan potensi dan konsep diri yang tertanam dalam diri sebenarnya (Hasbullah, 2001).

Karakter sudah ada dalam diri setiap individu, namun karakter tidak dapat berkembang dengan sendirinya. Proses pembentukan karakter hal terpenting adalah bagaimana pendidikan mampu memberikan kesadaran dari setiap peserta didik. Karakter religius merupakan salah satu yang ada dalam nilai karakter. Nilai religius menekankan pada karakter seseorang yang berhubungan dengan Tuhan. Namun nilai religius tersebut diterapkan dalam kehidupan sehari-hari terkait hubungan dengan manusia lainnya dan juga lingkungan sekitarnya. Karakter religius merupakan karakter yang sangat penting karena dapat mempengaruhi karakter lain. Religius menurut Syafri (2012) merupakan suatu sikap dan perilaku yang patuh dalam menjalankan atau melaksanakan ajaran agama yang dianutnya, toleran terhadap pelaksanaan ibadah agama lainnya dan hidup rukun dengan pemeluk agama lain.

Pendidikan karakter menurut Kementrian Pendidikan Nasional (2010), dimaknai sebagai pendidikan yang mengembangkan dan menanamkan karakter bangsa pada diri peserta didik sehingga mereka memiliki nilai dan karakter sebagai karakter dirinya, menerapkan nilai-nilai tersebut dalam kehidupan dirinya, sebagai anggota masyarakat, dan warga negara yang religius, nasionalis, produktif dan kreatif. Pendidikan karakter menurut Lickona (2013) sebagai upaya sungguh-sungguh untuk membantu seseorang memahami, peduli, dan bertindak dengan landasan inti nilai-nilai etis. Pendidikan karakter dapat dilakukan dengan mempertimpangkan beberapa aspek pendekatan.

Penelitian ini memiliki beberapa rumusan masalah, yaitu 1) Bagaimana implementasi penguatan pendidikan karakter religius diterapkan terutama melalui Mata Pelajaran Agama Islam dan PPKN 2) Bagaimana implementasi penguatan pendidikan karakter religius melalui pengembangan budaya sekolah 3) Bagaimana dampak implementasi penguatan pendidikan karakter religius pada peserta didik. Tujuan adanya penelitian ini yaitu untuk (1) Mendeskripsikan bagaimana implementasi penguatan pendidikan karakter religius yang diterapkan terutama melalui mata pelajaran agama dan PPKN (2) Mendeskripsikan bagaimana implementasi penguatan pendidikan karakter religius melalui pengembangan budaya sekolah (3) Mendeskripsikan bagaimana dampak implementasi penguatan pendidikan karakter religius pada peserta didik.

Penelitian terdahulu yang dilakukan oleh Susi Suprihatin (2017) berjudul Implementasi Nilai Religius dalam Kegiatan Pembelajaran PPKN dan Ekstrakurikuler di Sekolah Menengah Atas. Berdasarkan penelitian ini, penerapan nilai religius yang telah dilakukan di sekolah dapat memberikan dampak baik bagi peserta didik. Hal tersebut telah dibuktikannya beberapa perilaku yang biasanya dilakukan di sekolah dapat pula diimplementasikan dalam kehidupan sehari-hari atau dalam lingkungan rumah. Hambatan dalam pelaksanaan nilai religius dalam 
kegiatan pembelajaran PPKN dan kegiatan ekstrakurikuler yaitu kurangnya waktu tatap muka, tingkat pemahaman siswa, lingkungan dan juga pengawasan dari sekolah.

Diketahui dari penjelasan tersebut bahwa terdapat keterkaitan antara Implementasi Nilai Religius dalam Kegiatan Pembelajaran PPKN dan Ekstrakurikuler dengan Implementasi Pendidikan Karakter Religius di sekolah yang diharapkan dapat melahirkan generasi penerus bangsa yang berkarakter. Oleh karena itu, peneliti tertarik melakukan penelitian mengenai Implementasi Penguatan pendidikan Karakter Religius untuk menerapkan nilai religius. Berdasarkan uraian diatas, peneliti merangkainya dalam sebuah judul penelitian, yaitu implementasi penguatan pendidikan karakter religius.

\section{Metode}

Penelitian Implementasi Pendidikan Karakter Religius ini menggunakan pendekatan kualitatif, karena penelitian ini bertujuan untuk mendeskripsikan sesuatu yang menunjukkan bagaimana suatu kejadian dapat terjadi. Pendekatan kualitatif merupakan suatu proses penelitian dan pemahaman yang berdasarkan pada metodologi yang menyelidiki suatu fenomena sosial masalah manusia.

Prosedur pengumpulan data observasi, wawancara dan studi dokumen karena sangat penting dilakukan untuk mendapatkan data yang valid dan terpercaya. Analisis data memberikan makna terhadap data yang telah dikumpulkan, dilakukan analisis dan interpretasi. Mengingat penelitian ini dilakukan melalui pendekatan kualitatif, maka analisis dilakukan sejak data pertama sampai penelitian berakhir. Aktivitas dalam analisis data yang akan digunakan dalam penelitian ini, yaitu reduksi data, penyajian data, dan penarikan kesimpulan.

\section{Hasil dan Pembahasan}

\subsection{Implementasi Penguatan Pendidikan Karakter Religius}

Penguatan pendidikan karakter (character education) atau pendidikan moral (moral education) dalam masa ini perlu diimplementasikan untuk mengatasi krisis moral yang sedang melanda negeri ini. Hadirnya penguatan pendidikan karakter memiliki peran yang sangat penting, karena perubahan perilaku peserta didik (sebagai hasil dari proses pendidikan karakter) sangat ditentukan oleh faktor lingkungan. Dengan kata lain, pembentukan dan lingkungan yang mencakup diantaranya lingkungan fisik dan budaya sekolah, manajemen sekolah, kurikulum, pendidik, dan metode mengajar.

Salah satu upaya Sekolah dalam meningkatkan kualitas pendidikan dilakukan dengan implementasi nilai-nilai dalam pendidikan karakter. Nilai karakter religius menjadi highlight menggambarkan ciri khas khusus. Nilai religius dalam pendidikan karakter diimplementasikan dalam proses pembelajaran. Proses pembelajaran, nilai karakter diterapkan ke dalam materi dan kebiasaaan.

Penggunaan kegiatan pembiasaan ini tentu memiliki alasan yang kuat. Karena memang penanaman karakter yang paling kuat adalah melalui kegiatan pembiasaan. Hal ini juga diungkapkan oleh Licktona (2008) bahwa pendidikan moral untuk anak memerlukan kegiatan secara berulang ulang untuk melatih menjadi orang yang baik dimana anak harus diberikan 
kesempatan secara terus menerus berbuat jujur, bersikap santun dan adil sehingga menjadi sebuah kebiasaan yang selalu dilakukan dalam keadaan yang sulit sekalipun.

Kegiatan pembiasaan ini untuk membentuk mindset serta karakter anak secara tidak langsung dengan menempatkan mereka pada posisi yang sama setiap hari atau berkali-kali. Hal inilah yang membuat pemerintah terus mengupayakan kegiatan yang berhubungan dengan pendidikan karakter dan menyampaikan himbauan pada seluruh sekolah.

\subsection{Implementasi Penguatan Pendidikan Karakter Religius melalui Mata Pelajaran PPKN dan Agama}

Pendidikan karakter dinilai sangat penting ditanamkan semenjak anak usia dini karena masih sangat mudah untuk diarahkan dan dibentuk karakternya. Di lingkungan sekolah seharusnya porsi tentang perkembangan kepribadian atau kecakapan hidup diberikan lebih dominan dibandingkan dengan pemberian ilmu yang bersifat kognitif. Semakin tinggi jenjang satuan pendidikan yang ditempuh oleh peserta didik, maka semakin sedikit porsi yang diberikan untuk mengembangkan kepribadian dan lebih banyak pengetahuan-pengetahuan kognitif. Lingkungan sekolah merupakan sarana yang strategis untuk melaksanakan pendidikan karakter karena sebagian besar anak menghabiskan waktunya di sekolah sehingga sesuatu yang diperolehnya di sekolah akan berpengaruh kepada internalisasi karakternya.

Butir-butir nilai yang dikembangkan dalam pendidikan budaya dan karakter bangsa dikelompokan menjadi lima nilai utama yaitu nilai karakter dalam hubungannya dengan Tuhan, diri sendiri, sesama, lingkungan, dan kebangsaan. Nilai karakter yang hubungannya dengan Allah adalah nilai religius. Nilai karakter yang hubungannya dengan diri sendiri adalah nilai jujur, disiplin, kerja keras, kreatif, mandiri, rasa ingin tahu, gemar membaca dan tanggung jawab. Nilai religius merupakan salah satu nilai dari 18 nilai yang ada dalam pendidikan karakter. Nilai religius merupakan nilai yang berhubungan dengan Tuhan.

Pengembangan karakter dilakukan dengan tiga tahap seperti Tahap pertama yaitu perencanaan Rencana Pelaksanaan Pembelajaran (RPP) yang dilakukan sekolah adalah melalui hasil evaluasi pada tahun sebelumnya yang kemudian mencoba merumuskan solusi yang tepat dari ketidaksesuaian kegiatan yang telah berlangsung.

Tahap kedua yaitu tindakan. Tindakan disini merupakan sebuah upaya yang dilakukan sekolah dalam menerapkan karakter religius yang sebelumnya telah disepakati. Tindakan ini dapat berupa pembelajaran dalam kelas maupun kegiatan yang dilakukan di luar kelas yang masih dalam lingkungan sekolah. Tahap ketiga yaitu evaluasi. Evaluasi merupakan tahap terakhir dalam tahap implementasi karakter ini. Evaluasi berupa hasil kuantitatif yang diberikan tenaga pendidik yang diberikan kepada peserta didik dengan didasarkan pada persepsi tenaga pendidik atas ketercapaian penilaian.

Berkaitan dengan mata pelajaran agama, implementasi karakter religius berkaitan keimanan dan ketakwaan kepada Tuhan. Ajaran agama Islam terdiri dari tiga komponen utama yang menjadi bahasan yaitu: aqidah, akhlak dan fiqih. Materi pembelajaran dalam mata pelajaran agama yang diberikan berkaitan dengan optimisme, ikhtiar dan tawakal.

Berkaitan dengan mata pelajaran PPKn, implementasi karakter religius disesuaikan dengan nilai intrinsik dan nilai ekstrinsik yang tercantum dalam butir Pancasila, khususnya 
pada butir pertama Pancasila yang berbunyi "Ketuhanan Yang Maha Esa". Materi pembelajaran yang berkaitan dengan karakter religius yaitu cara menghormati, menghargai dan toleransi terhadap perbedaan agama.

\subsection{Implementasi Pendidikan Karakter Melalui Pengembangan Budaya Sekolah}

Implementasi karakter religius melalui pengembangan budaya sekolah diimplementasikan secara langsung dan tidak langsung. Implementasi karakter religius secara langsung dilakukan melalui kegiatan pembiasaan. Kegiatan pembiasaan ini membentuk skema kebiasaan yang terkoordinir dengan baik mulai dari peserta didik datang ke sekolah, sebelum pembelajaran di dalam ruang kelas, saat dalam pembelajaran dalam kelas, hingga berakhirnya kegiatan pembelajaran dan rangkaian kegiatan khusus di luar pembelajaran.

Secara langsung ada beberapa kegiatan yang mengimplementasikan karakter religius terbagi menjadi dua yaitu: (1) Kegiatan dalam Proses Pembelajaran dalam Kelas: Baris dan Bersalaman, Baca Al-Qur'an, Literasi. (2) Kegiatan diluar Proses Pembelajaran dalam Kelas: Sholat Dhuha, Sholat Berjamaah, seperti: Sholat Dzuhur, Sholat Ashar, Sholat Jumat, Peringatan Hari Besar Agama Islam, Jumat Sedekah, Jumat Bersih, Jumat Sehat, Jumat Inspiratif, Jumat Berdakwah. Secara tidak langsung implementasi karakter religius juga diimplementasikan dengan motivasi kepada peserta didik. Motivasi yang diberikan dapat berupa contoh perilaku, perbuatan dan kebiasaan. Harapannya dari implementasi karakter religius dapat menumbuhkan dan mengembangkan yang mengakar dengan kebiasaan para peserta didik.

\subsection{Dampak Budaya Karakter Religius Terhadap Peserta didik}

Implementasi karakter religius memiliki dampak terhadap pembentukan pendidikan karakter peserta didik. Sekolah yang konsisten mendukung kebijakan pemerintah dalam menerapkan pendidikan berbasis karakter. Hal ini didukung dari visi program penguatan pendidikan karakter antaranya: mandiri, berbudaya lingkungan hidup, dan berjiwa nasionalis berdasarkan IMTAQ serta mampu bersaing di era global. Memiliki kesesuaian dengan fungsi pendidikan nasional yang tertuang dalam UU Pasal 3 Nomor 20 Tahun 2003 yaitu mengembangkan potensi peserta didik agar menjadi manusia yang beriman dan bertakwa kepada Tuhan Yang Maha Esa, berakhlak mulia, sehat, berilmu, cakap, kreatif, mandiri dan menjadi warga negara yang demokratis serta bertanggung jawab.

Dalam mata pelajaran melalui pembiasaan adalah proses yang berkesinambungan dalam memberikan stimulus kesadaran para peserta didik agar memiliki kesadaran tanggung jawab dengan sendirinya karakter yang baik akan terbentuk dalam diri setiap peserta didik.

Implementasi karakter religius dalam pendidikan agama menjadi budaya religius yang diharapkan dapat membentuk karakter peserta didik memiliki kesesuaian dengan apa yang menjadi kebutuhan peserta didik untuk membentengi diri dari pergaulan bebas dan menangkal diri dari informasi negatif.

Budaya yang dikembangkan di sekolah sebagai proses melatih dan membina peserta didik untuk disiplin dalam menggunakan waktu dengan cara shalat tepat waktu dan berjamaah, melaksanakan Sholat Dhuha dan meningkatkan religiusitas peserta didik dengan membiasakan dengan berdo'a, membaca Al-Qur'an. Kebiasaan ini mendapatkan respon yang baik terkait kebiasaan tersebut. Pelaksanaan pendidikan karakter melalui budaya sekolah 
difokuskan pada karakter agama, disiplin, dan kemandirian. Setiap karakter diperoleh melalui kegiatan rutin, kegiatan spontan, dan keteladanan.

Dampak implementasi karakter religius memberikan peran khusus dalam Penguatan Pendidikan Karakter (PPK). Karakter religius diimplementasikan dalam beberapa kegiatan keseharian yang kemudian menjadi sebuah kebiasaan baru yang membentuk komitmen peserta didik menerapkan nilai-nilai agama di kehidupan sehari-hari. Hal menjadi bukti bahwa kegiatan sebagai Penguatan Pendidikan Karakter (PPK) yang mendukung program pemerintah dalam perbaikan dari segi pendidikan dapat terlaksana dengan baik dan terus-menerus.

Religius juga berkaitan dengan perilaku ritual yang berhubungan dengan kepercayaan. Kepercayaan tersebut yang mencakup afiliasi dan kepemilikan, perilaku dan praktik, kepercayaan dan nilai-nilai, dan pengalaman agama dan spiritual. Jadi pendapat ini menjelaskan bahwa religius berkaitan dengan kegiatan spiritual yang dilakukan oleh seseorang dalam kehidupan sehari-harinya. Spiritual ini muncul berdasarkan kepercayaan yang dianutnya. Jadi religius merupakan sesuatu sikap mental seseorang yang berhubungan dengan kepercayaan terhadap agama tertentu, serta perilaku patuh terhadap ajaran agama tersebut dengan menjalankan ibadah-ibadah tertentu dalam kehidupan sehari-hari.

Dampak terbesar dari implementasi nilai karakter ini didasarkan pada hasil feedback yang diberikan dari wali murid kepada pihak sekolah. Implikasi yang dirasakan setelah diterapkannya budaya religius ini adalah banyak terjadi perubahan dari peserta didik dan respon positif dari wali murid.

Pada tataran nilai yang dianut, memiliki komitmen bersama dalam mengembangkan karakter religius antara semua warga sekolah. Tataran praktik keseharian, karakter religius diwujudkan dalam bentuk sikap dan perilaku keseharian oleh seluruh warga sekolah. Tataran simbol budaya diberlakukan cara berpakaian dengan prinsip yang sesuai norma atau aturan yang berlaku di masyarakat.

\subsubsection{Sholat Dhuha}

Kebiasaan sholat dhuha dilakukan oleh peserta didik dan guru. Kebiasaan ini dilakukan pada jam ke-0 sebelum mata pelajaran dalam kelas dimulai. Peserta didik diajarkan untuk datang ke sekolah dengan sudah memiliki wudhu agar dapat langsung melakukan ibadah sholat dhuha. Adapun pendidikan karakter yang dirasakan dari pembiasaan shalat dhuha ini adalah kepatuhan atau religius.

\subsubsection{Baris dan Bersalaman}

Kebiasaan baris dan bersalaman dilakukan peserta didik sebelum kegiatan pembelajaran di dalam kelas dilakukan. Para peserta didik dibiasakan untuk menerapkan kebiasaan baris-berbaris dan bersalaman kepada guru untuk nilai disiplin, sedangkan bersalaman dengan guru mengarah kepada karakter religius. Karakter religius yang dimaksudkan yaitu saling menghargai dan menghormati, antara peserta didik kepada guru. 


\subsubsection{Baca Al-Qur'an}

Kebiasaan berdo'a dan membaca Al-Qur'an sebelum memulai mata pelajaran dilakukan peserta didik. Peserta didik dibiasakan berdo'a menurut kepercayaan dan keyakinan masingmasing untuk dapat berkah atas kegiatan yang akan dilakukan. Selanjutnya bagi peserta didik yang beragama muslim, pembiasaan membaca Al-Qur'an dilakukan dengan mengikuti panduan Tata Usaha (TU) sebagai pusat sebagai panduan untuk doa bersama yang kemudian dilanjutkan dengan membaca Al-Qur'an meneruskan bacaan sebelumnya. Adapun pendidikan karakter yang dirasakan dari pembiasaan membaca Al-Qur'an ini adalah kepatuhan atau religius.

\subsubsection{Literasi}

Membaca Al-Qur'an selesai kemudian, peserta didik dibiasakan dengan melakukan literasi keagamaan selama 15 menit. Kebiasaan literasi ini diterapkan kepada peserta didik, khususnya saat mengikuti mata pelajaran agama. Harapannya peserta didik akan terbiasa membaca dan mendapatkan banyak wawasan baru. Adapun pendidikan karakter yang dirasakan dari pembiasaan literasi ini merupakan religius, yaitu sikap dan perilaku yang patuh dalam melaksanakan ajaran agama dan toleran terhadap pelaksanaan agama lain serta hidup rukun dengan pemeluk agama lain.

\subsubsection{Sholat Berjamaah}

Kebiasaan sholat berjamaah bagi peserta didik yang beragama muslim. Sholat dzuhur dan ashar secara berjamaah ini selain membiasakan peserta didik untuk menjalankan kewajibannya, juga diharapkan dapat membiasakan peserta didik untuk menjalankan ibadah sholat lebih awal waktu dan dilakukan secara berjamaah sesuai dengan ajaran Rasul. Adapun pendidikan karakter yang dirasakan dari pembiasaan sholat berjamaah merupakan religius dan kepatuhan akan ajaran agama.

\subsubsection{Peringatan Hari Besar Agama}

Peringatan hari besar agama sebagai bentuk rasa syukur dan perekatan emosi, dimana setiap pelaksanaan peringatan selalu mengikutsertakan secara keseluruhan warga sekolah. Peringatan hari besar agama melibatkan semua bagian baik peserta didik, guru dan karyawan dalam setiap pelaksanaan peringatan. Setiap kegiatan menumbuhkan karakter religius, aturan dalam melaksanakan ajaran dan berpikir kreatif dalam melakukan serangkaian kegiatan.

\subsubsection{Jumat Sedekah}

Jumat sedekah dilakukan dengan membagikan nasi bungkus kepada warga di sekitar sekolah. Kegiatan amal ini dikoordinir dan dijadwalkan secara rutin oleh wali kelas. Adapun pendidikan karakter yang dirasakan dari pembiasaan Jumat sedekah atau Jumat menabung merupakan religius, peduli dan empati untuk membentuk kebiasaan berbagi terhadap sesama serta melatih kepedulian kepada sesama manusia yang hidup saling membantu. 


\subsubsection{Jumat Bersih dan Jumat Sehat}

Kebiasaan Jumat bersih dilakukan untuk meningkatkan kesadaran warga akan pentingnya lingkungan yang bersih dan sehat. Hal ini sesuai dengan hadist Nabi, sebagaimana disebutkan bahwa kebersihan adalah sebagian dari iman. Adapun karakter yang dapat dirasakan dalam kebiasaan Jumat bersih dan sehat adalah karakter peduli akan lingkungan dan tanggung jawab. Jumat sehat merupakan kegiatan pagi yang meliputi senam atau olahraga fisik. Sisi religius, manfaat jumat sehat untuk mengingatkan bahwa kebersihan dan kesehatan merupakan sebagian dari iman. Selain karakter religius, Jumat sehat juga memperkuat karakter mandiri. Kesehatan harus dimulai dari diri sendiri dan lingkungan.

\subsubsection{Jumat Inspiratif}

Kebiasaan Jumat inspiratif merupakan mendengarkan motivasi dengan narasumber yang berasal dari alumni .Para alumni diundang untuk memberikan dorongan dan motivasi khusus untuk membangun optimisme peserta didik dalam mempersiapkan tujuan masa depan. Adapun karakter yang dapat dirasakan dalam kebiasaan Jumat inspiratif merupakan karakter peduli.

\subsubsection{Jumat Berdakwah}

Kebiasaan Jumat berdakwah merupakan suatu kegiatan untuk melatih keberanian peserta didik untuk berbicara di depan umum. Materi yang disampaikan terkait dengan ilmu keagamaan. Adapun karakter yang dapat dirasakan dalam kebiasaan Jumat berdakwah dan sehat adalah karakter percaya diri, berani dan religius.

Karakter budaya religius merupakan kumpulan nilai agama yang melandasi perilaku, tradisi, kebiasaan keseharian dan simbol-simbol yang dipraktikkan oleh secara keseluruhan warga sekolah baik kepala sekolah, guru, karyawan, peserta didik dan masyarakat sekolah. Budaya tidak hanya berbentuk simbolik, tetapi harus penuh nilai dan membutuhkan sebuah proses pembudayaan.

Strategi pendidikan karakter religius yang dilakukan guru di sekolah yaitu melalui keteladanan dilakukan dengan guru memberikan contoh, pengertian, nasihat kepada siswa, pembelajaran dilakukan dengan guru mengaitkan materi dengan aspek religius, pemberdayaan dan pembudayaan dilakukan dengan penerapan tata tertib sekolah dan kegiatan ekstrakurikuler, penguatan dilakukan dengan guru memberikan pengertian, pujian dan motivasi siswa,dan penilaian dilakukan dengan mengamati sikap siswa.

Kedisiplinan dan pembiasaan sehari-hari berperan penting dalam membentuk karakter anak. Penjadwalan dan pembiasaan menjadikan karakter positif melekat pada diri anak. Jadi proses terbentuknya perilaku religius pada anak usia dini yaitu diawali dengan memberikan pemahaman tentang nilai-nilai religius pada anak yang diikuti dengan contoh serta pembiasaan perilaku orang dewasa agar anak dapat melihat perilaku tersebut dengan konkrit sehingga menimbulkan rasa butuh untuk menerapkan perilaku tersebut.

\section{Simpulan}

Berdasarkan hasil penelitian dan pembahasan yang telah diuraikan mengenai implementasi penguatan pendidikan karakter religius dikemukakan kesimpulan penelitian 
yaitu implementasi penguatan pendidikan karakter di sekolah memiliki 10 kegiatan pembiasaan yang mengimplementasikan karakter religius yang diterapkan di sekolah. Karakter religius merupakan kumpulan nilai agama yang melandasi perilaku, tradisi, simbol dan kebiasaan-kebiasaan yang dipraktikkan oleh masyarakat sekolah. Adapun 10 kegiatan pembiasaan karakter religius adalah sebagai berikut: sholat dhuha pada saat jam ke-0, baris dan bersalaman, membaca Al-Qur'an, berdoa, literasi, sholat berjamaah, peringatan hari besar agama, Jumat sedekah, Jumat bersih dan Jumat sehat, Jumat inspiratif dan Jumat berdakwah. Dampak implementasi karakter religius memiliki implikasi yang positif. Implikasi karakter didukung dengan komitmen dan konsistensi yang besar antara pihak sekolah dengan wali murid dalam membentuk karakter peserta didik yang berkaitan dengan iman dan taqwa terpenuhi.

\section{Daftar Rujukan}

Andiarini, S. E., \& Nurabadi, A. (2018). Implementasi program penguatan pendidikan karakter melalui kegiatan pembiasaan dalam peningkatan mutu sekolah. JAMP: Jurnal Administrasi dan Manajemen Pendidikan, 1(2), 238-244.

Annis, T. (2014). Pelaksanaan Nilai Religius Dalam Pendidikan Karakter Di SD Negeri 1 Kutowinangun Kebumen. Jurnal UNY, 3(08).

Arikunto, S. (2014). Metode penelitian kuantitatif, kualitatif, dan kombinasi (mixed methods). Bandung: Alfabeta.

Bahri, S. (2015). Implementasi pendidikan karakter dalam mengatasi krisis moral di sekolah. Ta'allum: Jurnal Pendidikan Islam, 3(1), 57-76.

Dewi, A. K. T., Degeng, I. N. S., \& Hadi, S. (2019). Implementasi pendidikan nilai karakter di Sekolah Dasar melalui budaya sekolah. Jurnal Pendidikan: Teori, Penelitian, dan Pengembangan, 4(2), 247-255.

Gunawan, H. (2012). Pendidikan Karakter Konsep dan Implementasi. Bandung: Alfabeta.

Hambali, M., \& Yulianti, E. (2018). Ekstrakurikuler keagamaan terhadap pembentukan karakter religius peserta didik di kota majapahit. PEDAGOGIK: Jurnal Pendidikan, 5(2), 193-208.

Hendriana, E. C., \& Jacobus, A. (2017). Implementasi pendidikan karakter di sekolah melalui keteladanan dan pembiasaan. JPDI (Jurnal Pendidikan Dasar Indonesia), 1(2), 25-29.

Jumarudin, J., Gafur, A., \& Suardiman, S. P. (2014). Pengembangan model pembelajaran humanis religius dalam pendidikan karakter di sekolah dasar. Jurnal Pembangunan Pendidikan: Fondasi dan Aplikasi, 2(2).

Lickona, T. (2013). Pendidikan karakter panduan lengkap mendidik siswa menjadi pintar dan baik. Bandung: Nusa Media.

Maisaro, A., Wiyono, B. B., \& Arifin, I. (2018). Manajemen program penguatan pendidikan karakter di sekolah dasar. JAMP: Jurnal Administrasi dan Manajemen Pendidikan, 1(3), 302-312.

Majid, A. (2014). Pendidikan Berbasis Ketuhanan: Membangun Manusia Berkarakter. Bogor: Ghalia Indonesia.

Sahlan, A. (2010). Mewujudkan Budaya Religius di Sekolah: Upaya Mengembangkan PAI dari Teori ke Aksi. UINMaliki Press.

Sujianto, S. (2008). Implementasi Kebijakan Publik Konsep Teori dan Praktek. Jakarta: Alfabeta.

Trimuliana, I., Dhieni, N., \& Hapidin, H. (2019). Perilaku Religius Anak Usia 5-6 Tahun pada PAUD Model Karakter. Jurnal Obsesi: Jurnal Pendidikan Anak Usia Dini, 3(2), 570-577.

Usman, N. (2002). Konteks implementasi berbasis Kurikulum. Jakarta: Grasindo.

Wangid, M. N. (2010). Peran konselor sekolah dalam pendidikan karakter. Jurnal Cakrawala Pendidikan, 1(3).

Zubaedi, D. P. K. (2011). Konsepsi dan Aplikasinya dalam Lembaga Pendidikan. Jakarta: Kencana. 